\title{
Comprehensive Counseling Guidance Model in Providing Pre-Marriage Services for Students
}

\author{
Fatmawati ${ }^{1}$, Nurhastuti ${ }^{2}$ \\ ${ }^{1} 2$ Universitas Negeri Padang \\ * e-mail: fatmawati@,fip.unp.ac.id
}

\begin{abstract}
Premarital education for students is considered necessary because, at this time, a person must be prepared to enter married life. Premarital education is one of the preparations that can be done by early adults in marriage and has a goal in preventing divorce. This study aims to formulate a hypothetical comprehensive guidance and counseling program to improve students' self-readiness in facing marriage and family life. This type of research is development research or Research and Development methods, namely research strategies used to produce specific products. This research is conducted at Padang State University, namely to students of Special Education, Faculty of Education. The results of this study are (1) In general, special education department's students of the Faculty of Education, Padang State University, as early adults, have less interest in preparing for their marriage. (2) The comprehensive premarital guidance and counseling model for students developed in this study is formulated from a theoretical framework based on field findings, consisting of 7 rational components, key concepts, vision \& mission, model objectives, the content of guidance and counseling, control, and organization \& personnel. (3) Based on the model validation test conducted by three counselors on the General Guidelines for the Development of Comprehensive Premarital Guidance and Models for Students, it shows that the contents of the general guidelines are categorized as suitable or adequate.
\end{abstract}

Keywords: Model; comprehensive guidance and counseling; premarital

How to cite : Fatmawati, F., \& Nurhastuti, N. (2021). Comprehensive Counseling Guidance Model In Providing Pre-Marriage Services For Students. Pedagogi: Jurnal Ilmu Pendidikan, 21(2), 128-133. https://doi.org/https://doi.org/10.24036/pedagogi.v21i2.1177

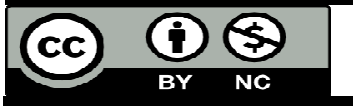

Licensees may copy, distribute, display and perform the work an make derivative and remixes based on it only if they give the author or licensor the credits (attributtion) in the manner specified by these. Licensees may copy, distribute, display, and perform the work and make derivative works and remixes based on it only for non-commercial purposes

\section{INTRODUCTION}

Premarital education is critical to note because it provides a reasonably primary contribution to family life. The critical part here is that the decline in the values of married life in the family is one of the most significant challenges of our time. Therefore, premarital education is a shared responsibility to form a family and even a better society (Yuhanis et al., 2020). Herein lies the intervention of higher education institutions to prepare prospective married couples to face the new life context that they have to live a lifetime of maturely (Karneli et al., 2018).

Students in higher education institutions are students aged between 18-25 years. According to Willis (2011), 18 years to 24 years is the age of early adulthood (young adulthood) (Willis, 2011). Students are entering the early adult phase, which is an age phase that demands to improve the quality of their knowledge further and skills and personal qualities as a provision to live independently (Fauziyah \& Maemonah, 2020). 
Turner \& Helms in (Dariyo, 2008) said that at the young adult stage, several developmental tasks must be fulfilled by each individual who is at this stage. One of them is looking for and finding a potential life partner. Judging from the developmental tasks that are being faced in the early adulthood phase, one of the developmental tasks being faced by students is "preparing for marriage and family life". Before finding a potential life partner and building an exit, many things must be prepared, one of which is premarital education. Marriage and family life readiness is one of aspects in Competency Standards of Independence that must be achieved by students at school. This concept is similar to the phases and tasks of adolescent development which begin to enter the early adult development phase (Choiriyah \& Al-Kattani, 2020)..

One way to provide premarital education to students is by providing counselling services (Samad et al., 2016). Premarital counselling is intended to help couples to analyze possible problems and challenges that will arise in their household and equip them with the skills to solve problems (Musnamar, 2005).

Related to the description above, it is necessary to make efforts to develop a model of guidance and counselling in tertiary institutions, which is developed based on the importance of readiness to marry and live a family following developmental tasks and religious values, as well as a comprehensive and in-depth study of the needs student facts about the service (Ningtyas \& Muis, 2017; Sari \& Sunarti, 2013). One approach to guidance and counselling that is expected to facilitate students' needs, especially regarding self-readiness for marriage and family life, is through a comprehensive guidance and counselling approach.

Based on the description of the phenomenon of premarital education above, in detail, the formulation of the research problem is described in the following research questions: "What is the formulation of a hypothetical comprehensive guidance and counseling program to improve students' self-readiness in facing marriage and family life?."

\section{METHODS}

This study aims to develop a model of premarital guidance and counselling with the target population of students. Achieving these goals requires an in-depth study of students' actual needs for premarital guidance and counselling services. Obtaining information regarding these aspects will be approached through a research and development approach that aims to develop. Research and development is a powerful strategy for improving practice. It is a process used to develop and validate educational products (Borg \& Gall, 1989).

This study used studen ts who become the population from 2014 to 2017 as the sample. This research will be conducted at Padang State University, namely to students of Special Education, Faculty of Education. In this study, the population who became respondents were students of Special Education, Faculty of Education, Padang State University. In this study, because the sample is known for sure and is permanent, the sample is statutory random sampling. Based on the sampling method, the number of samples in this study was 52 students.

\section{FINDING AND DISCUSSIONS}

\section{Findings}

Based on the results of observations obtained several problems of readiness of PLB students of the Faculty of Education, Padang State University in preparation for marriage. These problems can be inventoried as follows:

a. Problems related to student developmental tasks.

Based on the survey conducted, it was obtained data that PLB students from the Faculty of Education, Padang State University as early adults lacked interest in preparing for their marriage, and many reasons made students less concerned about marriage, including wanting to focus first on completing their studies.

b. Students have not been able to act following positive considerations in preparing themselves for marriage. 
Students of the special education department from the Faculty of Education, Padang State University, have a profile of readiness for marriage and family life in the low category, which indicates poor readiness in every aspect, namely the aspect of self-readiness in choosing a life partner; aspects of self-readiness to learn to live with a married partner; aspects of selfreadiness in family life; aspects of self-readiness in caring for and educating children; and aspects of self-readiness in managing the family household.

c. The phenomenon of marriage preparation for students has received less response and attention from the higher education institution.

In higher education institutions, the delivery of premarital education has received less attention. This can be seen from the relatively small portion of learning that can even be said to be almost non-existent (Muhadara et al., 2016). Unfortunately, students have to seek premarital education outside campus (Muntamah et al., 2019), even though in their daily life they study on campus, and it is appropriate that this paradoxical condition be addressed immediately.

\section{Development of Comprehensive Premarital Guidance and Counseling Models for Students}

The comprehensive premarital guidance and counselling model for students developed in this study was formulated from a theoretical framework based on-field findings. The comprehensive premarital guidance and counselling model for students consists of 7 components as follows:

a. Rational. The assumption of a comprehensive premarital guidance and counselling model for students is based on the fundamental theories used in developing a comprehensive premarital counselling and guidance model for students (Keshavarz et al., 2013).

b. Key Concept. Premarital guidance and counselling is a pattern of providing assistance aimed at helping students understand and respond to the concept of marriage and family life based on developmental tasks and religious values as a reference in preparing for the marriage they expect (Koenig, 2012).

c. Vision and Mission of Comprehensive Premarital Guidance and Counseling The vision of comprehensive premarital guidance and counselling for students is to realize optimal selfdevelopment and independence following their nature, both as individual beings or social beings. The general mission is to help and facilitate the alleviation of student problems referring to practical daily life. In this case, students' independence can live a family life that will be experienced in the future effectively (Afdal et al., 2019).

d. The Purpose of the Comprehensive Premarital Counseling Guidance Model. The purpose of the comprehensive premarital guidance and counselling model for students developed by researchers, in general, is to plan activities for completing studies, career development and preparing for future marriages.

e. Contents of Comprehensive Premarital Guidance and Counseling. The content of comprehensive premarital guidance and counselling for students is a work program of premarital guidance and counselling. The work program that the researcher has prepared contains the following: 1) Definition of Comprehensive Premarital Guidance and Counseling; 2) Counselor Role; 3) Counselor Function; 4) Counselor Qualification; 5) Work Procedures for Comprehensive Premarital Guidance and Counseling: a) Basic Guidance Service; b) Responsive Service; c) Individual Planning Service; end d) System Support; 6) Timing; 7)Interaction atmosphere; 8) Stages of Implementation of Comprehensive Premarital Guidance and Counseling: a) Identifying Cases; b) Problem Identification; c) Diagnose; d) Conducting Prognosis; e) Taking Remedial Actions; end Evaluation and Follow Up.

f. Control. Control is one of the crucial aspects in managing comprehensive premarital counselling and guidance services for students. The purpose of controlling the comprehensive premarital counselling and guidance program for students is to enable the smooth and effective implementation of the planned program.

g. Organization and Personnel. Comprehensive premarital guidance and counselling services for students are carried out under the head of the college and all staff (El-Ghany et al., 2010). The guidance and counselling coordinator is responsible for providing operational guidance and 
counselling. Other personnel, including counsellors, lecturers in the field of study, and student guardians, have their respective roles and duties in providing guidance and counselling services.

\section{Model Validation Test Result}

To test the validation of the comprehensive premarital guidance and counselling model for students, validation was carried out on the guidance and counselling model material, which can be obtained as follows.

Table 1. Model Validation Result

\begin{tabular}{|c|c|c|c|c|c|c|c|c|c|}
\hline \multirow[t]{2}{*}{ No. } & \multirow[t]{2}{*}{ Aspect } & \multicolumn{2}{|c|}{$\begin{array}{c}\text { Counsellor } \\
1\end{array}$} & \multicolumn{3}{|c|}{$\begin{array}{c}\text { Counsellor } \\
2 \\
\end{array}$} & \multicolumn{3}{|c|}{$\begin{array}{c}\text { Counsellor } \\
\mathbf{3}\end{array}$} \\
\hline & & B $\mathbf{S}$ & $\mathbf{B r}$ & $\mathbf{B}$ & $\mathbf{S}$ & $\overline{\mathbf{B r}}$ & $\mathbf{B}$ & $\mathbf{S}$ & $\overline{\mathbf{B r}}$ \\
\hline 1. & Rational & $\sqrt{ }$ & & $\sqrt{ }$ & & & $\sqrt{ }$ & & \\
\hline 2. & Key COncept & $\sqrt{ }$ & & $\sqrt{ }$ & & & $\sqrt{ }$ & & \\
\hline 3. & Vision and Mission & $\sqrt{ }$ & & $\sqrt{ }$ & & & $\sqrt{ }$ & & \\
\hline 4. & Model Goal & $\sqrt{ }$ & & $\sqrt{ }$ & & & $\sqrt{ }$ & & \\
\hline 5. & $\begin{array}{l}\text { Contents of Guidance and } \\
\text { Counselling }\end{array}$ & $\sqrt{ }$ & & $\sqrt{ }$ & & & $\sqrt{ }$ & & \\
\hline 6. & Control & $\sqrt{ }$ & & $\sqrt{ }$ & & & $\sqrt{ }$ & & \\
\hline 7. & Organization and Personnel & $\sqrt{ }$ & & $\sqrt{ }$ & & & $\sqrt{ }$ & & \\
\hline
\end{tabular}

$$
B=O K S=\text { Medium } \quad B r=\text { Bad }
$$

Based on the above model validation test conducted by three counsellors on the General Guidelines for the Development of Comprehensive Premarital Guidance and Model Models for Students, it shows that the contents of the general guidelines are categorized as reasonable or adequate, even for some materials it shows very good or very adequate, even there is no single material. Anything that indicates moderate, let alone significantly less excellent or adequate. This means that the substance of the general guidelines that have been developed can be used as a reference for providing premarital guidance and counselling services to students, especially for the development of students' mental readiness in building a family.

\section{DISCUSSION}

Students' self-readiness for marriage and family life is one of the developmental tasks at the age of students as individuals who are in the phase of early adulthood (Putri et al., 2018), in addition to undergoing other developmental tasks, such as completing college and preparing to enter a job, which is simultaneously being faced and need to be prepared carefully with a sense of independence.

Most students have not been able to act according to positive considerations in preparing themselves for marriage. In addition, students have not been able to commit to marriage, which they can firmly hold as a principle not to be independent and not confident .

Associated with the readiness of students in facing marriage and family life as well as the phenomenon of marriage and the conditions of the relationships that exist between students of the opposite sex, until now there tends to be no effective guidance and counseling service that can facilitate according to the needs of students, and or in providing appropriate treatment.

Parents are the first to set an example for their children. Parents determine the future of their children. However, they recognize the limitations and opportunities they have, so that the role of parents is also assisted by outsiders to educate their children (Harahap et al., 2021). Other parties are teachers, relatives, even grandmothers at school and at home. Parents play an important role in determining the success of children in finding the meaning of marriage. The attention of parents at home can help children find the meaning of marriage and their responsibilities which can be done by supervising and guiding children in solving problems in learning or in their daily lives (Mardiana, 2020; Rachmawaty, 2015). 
However, a comprehensive guidance and counseling approach is seen as a way that tends to be appropriate to increase students' readiness to face marriage and family life.

\section{CONCLUSION}

In general, PLB students from the Faculty of Education, Padang State University, as early adults, lack interest in preparing for their wedding. Many reasons make students less concerned about marriage, including wanting to focus first on completing their studies.

The comprehensive premarital guidance and counselling model for students developed in this study was formulated from a theoretical framework based on field findings, consisting of 7 rational components, key concepts, vision \& mission, model objectives, guidance and counselling content control, and organization \& personnel.

Based on the model validation test conducted by three counsellors on the General Guidelines for the Development of Comprehensive Premarital Guidance and Models for Students, it shows that the contents of the general guidelines are categorized as suitable or adequate.

\section{REFERENCES}

Afdal, Wulandari, E., Nirwana, H., Alizamar, A., \& Sukmawati, I. (2019). Premarital Counseling: Opportunities and Challenges in Industrial Revolution 4 . 0 Era. International Conference on Education Technology (ICoET 2019), 372(ICoET), 295-299.

Borg, W. ., \& Gall, M. . (1989). Educational Research: an Introduction, Fifthy Edition. Longman. Choiriyah, N., \& Al-Kattani, A. (2020). Islamic Guidance and Counseling Concept for Family Life Readiness Among High School Teenagers. Prophetic Guidance and Counseling Journal, 1, 35. https://doi.org/10.32832/pro-gcj.v1i1.2918

Dariyo, A. (2008). Psikologi Pengembangan Dewasa Muda. Grasindo Widia Sarana Indonesia.

El-Ghany, G., Gad, A., \& Al-Haddad, A. (2010). Knowledge and Attitude about Pre-Marital Counseling among Hadhramout University Students. Zagazig Nursing Journal, 6, 46-65.

Fauziyah, U. S., \& Maemonah, M. (2020). Analisis Tiger Parenting bagi Perkembangan Emosional Anak. Pedagogi: Jurnal Ilmu Pendidikan, 20(2), 80-90.

Harahap, H. S., Hrp, N. A., Nasution, I. B., Harahap, A., Harahap, A., \& Harahap, A. (2021). Hubungan Motivasi Berprestasi, Minat dan Perhatian Orang Tua terhadap Kemandirian Siswa. Edukatif: Jurnal Ilmu Pendidikan, 3(4), 1133-1143.

Karneli, Y., Firman, F., \& Netrawati, N. (2018). Upaya Guru BK/Konselor untuk Menurunkan Perilaku Agresif Siswa dengan Menggunakan Konseling Kreatif dalam Bingkai Modifikasi Kognitif Perilaku. Pedagogi: Jurnal Ilmu Pendidikan, 18(2), 113-118.

Keshavarz, A., Amrgha, H. A., \& 'Melatkhah, N. (2013). Effectiveness of Marriage Education Before Marriage Change Irrational Beliefs Girls. Procedia - Social and Behavioral Sciences, 84, 520-524. https://doi.org/10.1016/j.sbspro.2013.06.596

Koenig, H. G. (2012). Religion, Spirituality, and Health: The Research and Clinical Implications. ISRN Psychiatry, 2012, 1-33. https://doi.org/10.5402/2012/278730

Mardiana, N. S. (2020). Pengaruh Pola Asuh Otoriter Orang Tua terhadap Interaksi Anak Usia Dini. Pedagogi: Jurnal Ilmu Pendidikan, 20(1), 22-25.

Muhadara, I., Parawangi, A., \& Malik, I. (2016). Peran Pemerintah Daerah dalam Pengendalian Perkawinan Usia Dini di Kecamatan Polongbangkeng Utara Kabupaten Takalar. Jurnal Administrasi Publik, Volume 2 N(1).

Muntamah, A., Latifiani, D., \& Arifin, R. (2019). Pernikahan Dini di Indonesia: Faktor dan Peran Pemerintah (Perspektif Penegakan dan Perlindungan Hukum bagi Anak). Widya Yuridika, 2, 1. https://doi.org/10.31328/wy.v2i1.823

Musnamar, T. (2005). Dasar-dasar Konseptual Bimbingan dan Konseling Islami UII Press. UII Press.

Ningtyas, E. B., \& Muis, T. (2017). Studi tentang Self Management Mahasiswa yang sudah Menikah di Fakultas Ilmu Pendidikan UNESA. Jurnal UNNESA, 7(2), 1-7.

Putri, S. M., Khairani, K., \& Yusri, Y. (2018). Kesiapan Guru Kelas Melaksanakan Layanan 
Bimbingan dan Konseling di Sekolah Dasar Se-Kota Padang. Pedagogi: Jurnal Ilmu Pendidikan, 18(2), 119-124.

Rachmawaty, F. (2015). Peran Pola Asuh Orang Tua terhadap Kecemasan Sosial pada Remaja. Jurnal Psikologi Tabularasa, 10(1), 31-42.

Samad, D., Remiswal, R., Kenedi, G., \& Mustqim, M. (2016). The Effectiveness of Premarital Counseling Service on the Harmony of Marriage in Family Resilience. Al-Ta Lim Journal, 23(3), 214-223. https://doi.org/10.15548/jt.v23i3.254

Sari, F., \& Sunarti, E. (2013). Kesiapan Menikah pada Dewasa Muda dan Pengaruhnya terhadap Usia Menikah. Jurnal Ilmu Keluarga Dan Konsumen, 6, 143-153. https://doi.org/10.24156/jikk.2013.6.3.143

Willis, S. (2011). Remaja dan Masalahnya. Alfabeta.

Yuhanis, Y., Arafat, Y., \& Puspitasari, A. (2020). Implementation of Character Education in Fostering Elementary School Students in Gelumbang, Indonesia. Pedagogi: Jurnal Ilmu Pendidikan, 20(2), 60-68. 